УДК 94 (477.7) «17»

DOI: https://doi.org/10.33782/2708-4116.2020.1.14

Сергій Аргатюк, Ігор Сапожников*

\title{
ДНІСТРОВСЬКА ЕСКАДРА ЧОРНОМОРСЬКОГО ГРЕБНОГО ФЛОТУ ТА ІІЇ КОМАНДИР ХРИСТОФОР БЕРНАРД ДЕ ГРАВЕ
}

Анотація: Стаття присвячена історії Дністровської ескадри, утвореної після російськотурещької війни 1787-1791 рр., яка була бойовою одиниеею Чорноморського Гребного флоту, що базувався у Миколаєві й Одесі. У ній описана біографія першого командуючого Дністровської флотилії Х.Б. де Граве, значна частина життя та діяльності якого була пов'язана з обома містами. У статті вперше опубліковані плани з позначенням флотських споруд в Овідіополі 1794 i 1798 рр., які виконали Ф.П.де Волан і Є.Х. Ферстер. У додатку поданий детальний звіт контр-адмірала П.В. Пустошкіна про навігаційну кампанію 1797 року, який проливає світло на структуру та діяльність усього Гребного флоту в часи правління ілператора Павла I.

Ключові слова: Аджидер, Овідіополь, Дністровська флотилія, капітан Христофор Бернард де Граве, Миколаїв

Дністровська (Аджидерська, пізніше - Овідіопольська) гребна флотилія (ескадра) почала формуватися у 1792 р. Значна їі частина складалася з суден, захоплених у турків під час війни, а також нових кораблів, збудованих у Північно-Західному Причорномор'ї на верфях Аджидера, Бендер, Миколаєва, Галаца, Дубоссар. Так, лансони «Герасим», «Іассон», «Симеон», «Іустин», «Мануїл», «Захарій», «Дем'ян», «Євдоким» були захоплені у турків при Очакові 1788 р., а лансони «Яків», «Мавра», «Амос», «Леонтій», «Трофим», «Лаврентій», «Марк», «Ірина», «Ісідор», «Андроник», «Савва», «Дорофей», «Требака» перейшли до російського флоту при штурмі Ізмаїлу в 1790 р. Причому значна частина суден Гребного, як і всього Чорноморського флоту з 1783 по 1790-ті рр., змінювала свої назви принаймні один раз ${ }^{1}$.

Документи свідчать, що 1792 року капітану бригадирського рангу П.В. Пустошкіну наказали перевести увесь Гребний Чорноморський флот з Дунаю до Миколаєва та розташувати його у гирлі р. Інгул. Іншим наказом йому доручили конвоювати до острова Тамань флотилію Чорноморського козацького війська, при цьому залишити частину козацьких човнів на Дністровському лимані «для утримання сторожі при Аджидері» разом 3

\footnotetext{
"Аргатюк Сергій Степанович - вчитель історії загальноосвітньої школи (с. Прилиманське Овідіопольського району Одеської обл.); ORCID: https://orcid.org/0000-0002-2738-9218; e-mail: argatyukt@ukr.net

Сапожников Ігор Вікторович - доктор історичних наук, провідний науковий співробітник Відділу Криму та Північно-Західного Причорномор'я Інституту археології НАН України, член Національної спілки краєзнавців України; ORCID: https://orcid.org/0000-0003-3889-6714; e-mail: igors@gcn.ua

${ }^{1}$ Аргатюк С.С., Левчук В.В., Сапожников И.В. Аджидер-Овидиополь: очерки по археологии и истории города и крепости. Одесса, 2015. С. 147.
} 
суднами, що вже перебували тут під командою «капітан-лейтенанта Графа» 2.

3 його групи до Миколаєва відправили лише бригантину «Святий Іларіон», яка була завеликою для мілководного Дністровського лиману. Восени 1792 р. на шляху до бази флоту корабель спочатку затерло льодом на Дніпро-Бузькому лимані, а потім він сів на мілину біля с. Богоявленська, з якої її зняли лише навесні наступного року.

В інших документах йдеться власне про формування Дністровської ескадри. Перший 3 них - ордер командуючого обома Чорноморськими флотами віце-адмірала М.С. Мордвинова на ім'я П.В. Пустошкіна. Йому приписувалося додати до залишених на Дністрі 60 непридатних козацьких човнів, 6 колишніх турецьких баркасів і суден, а також збудувати на місці ще 15 човнів. Головним завданням нової ескадри, начальником якої призначили капітан-лейтенанта Графа, було боронити новий кордон. У другому документі, а саме листі М.С. Мордвинова до імператриці Катерини II від 6 липня 1792 р., повідомлялося, що в Аджидері під командою Графа залишили 10 великих човнів без артилерії, 15 нових суден і 6 баркасів. Ліс для будівництва суден з Дунаю і корабельних майстрів капітану П.В. Пустошкіну наказали доправити до Миколаєва 3 .

Згаданий у документах капітан Граф виявився Христофором Христофоровичем Бернардом де Граве, який народився у 1752 р. (за іншим джерелом - 1758 р.). 16.02.1764 p. він поступив до морського кадетського корпусу, а 01.03.1770 р. був переведений до морської артилерії. У роки 1770-1775 рр. ходив на Балтійському морі. 308.03 .1772 р. - констапель (старшина) морської артилерії, до 1780 р. знаходився у Кронштадті, а до 1783 р. - у Петербурзі при артилерійських командах, де 6 лютого отримав звання мічмана. 1784 року був відряджений до Казані для отримання рекрутів, яких доправив до Херсону. 31785 по 1787 роки плавав у Чорному морі. 23.03.1787 р. отримав звання лейтенанта і командував артилерійською батареєю № 1 в ескадрі контр-адмірала М.С. Мордвинова під Очаковом. Наступного року керував плавучою батареєю № 4 на Дніпровсько-Бузькому лимані та відзначився у битвах з турками, за що 4 вересня отримав звання капітан-лейтенанта. У 1789 р. перебував у Києві, де займався замірами й описом гармат морської та облогової артилерії; 23 червня був призначений радником інтендантської експедиції над магазинами; 28 червня - капітаном нового Миколаївського порту, де пробув до 1790 р. ${ }^{4}$

Якимось чином Х.Б. де Граве став учасником штурму Ізмаїльської фортеці наприкінці 1790 р. У реляції О.В. Суворова він записаний як «капітан Хрестьян Греве бомбардирського полку» ${ }^{5}$, а наступного року відзначився у битві при Бабадазі, про що 11.06.1791 p. М.I. Кутузов повідомив М.В. Репніну, зазначивши, що там «всією польовою батареєю, розділеною по кареям, командував бомбардирського полку капітан Граве» ${ }^{6}$.

У 1791 р. він привів з Бендер до Миколаєва нові бригантини. А з 1792 по 1795 рр. командував Дністровською гребною флотилією на лимані, звідки 1793 року Х.Б. де Граве був відряджений для вимірювання глибин фарватеру р. Дністер до австрійського містечка

\footnotetext{
${ }^{2}$ Описание дел Архива Морского Министерства за время с половины XVII до начала XIX столетия. Т. X. Санкт-Петербург, 1906. С. 114.

${ }^{3}$ Аргатюк С.С., Левчук В.В., Сапожников И.В. Указ. соч. С. 147-150.

${ }^{4}$ Общий морской список. Ч. ІІІ: Царствование Екатерины II. А-К. Санкт-Петербург, 1890. С. 429-430.

${ }^{5}$ Красницкий А.И. Русский чудо-вождь. Граф Суворов-Рымникский, князь Италийский, его жизнь и подвиги. Санкт-Петербург, 1900. С. 252.

${ }^{6}$ М.И. Кутузов: Сборник документов и материалов / Л.Г. Бескровный (ред.) Т. 1. Москва, 1950. С. 144.
} 
Окопи (у Тернопільській області) ${ }^{7}$

Після залишення козаками Дністровського лиману, ескадра поповнювалася новими човнами. Спочатку, за планом адмірала М.С. Мордвинова, в Аджидері планували збудувати 10 або 25 човнів. Проте, як свідчить лист О.В. Суворова на ім'я П.О. Зубова від 20.01.1793 р., обсяги будівництва в Аджидері були втричі більшими. Тут збудували 50 військових човнів і 72 гребних судна різних типів. Зрозуміло, що такі значні масштаби будівництва флотилії вимагали значних матеріальних і людських ресурсів. Відомо, що 3 травня 1792 р. тут знаходилася інженерна команда, підпорядкована полковнику Олексопольського полку полковнику Г.О. Гагенмейстеру, від якого полковий осавул А. Височина прийняв необхідні для оснащення ввірених йому козацьких човнів «матеріали і речі», тобто, цей підрозділ мав відношення до адміралтейства та судноверфі.

Звідси витікає, що 3 літа 1792 р. в Аджидері почали будувати спочатку козацькі, а потім більші за розмірами судна для Гребної флотилії. Проте невідомо, скільки з них потрапило до складу власне Дністровської флотилії. Виготовлені в Аджидері 50 канонірських човнів мали довжину 60, а ширину 15, глибиною кіля по борту 7 футів 4 дюйми (Рис. 1). Для їх озброєння на Херсонському ливарному заводі виплавили 18-фунтові гармати. А в лютому 1793 р. з казни виділили 28291 руб. для розрахунку за перевезення гармат до Аджидеру. У 1794 р. з Молдови і Галичини через Дубосари до Аджидеру доправили ліс для виготовлення щогол і рей. Значна частина збудованих там суден вийшла в Чорне море і вже 30 травня 1794 р. стояла на рейді Хаджибея під командою віце-адмірала Й.М. де Рібаса 8 .

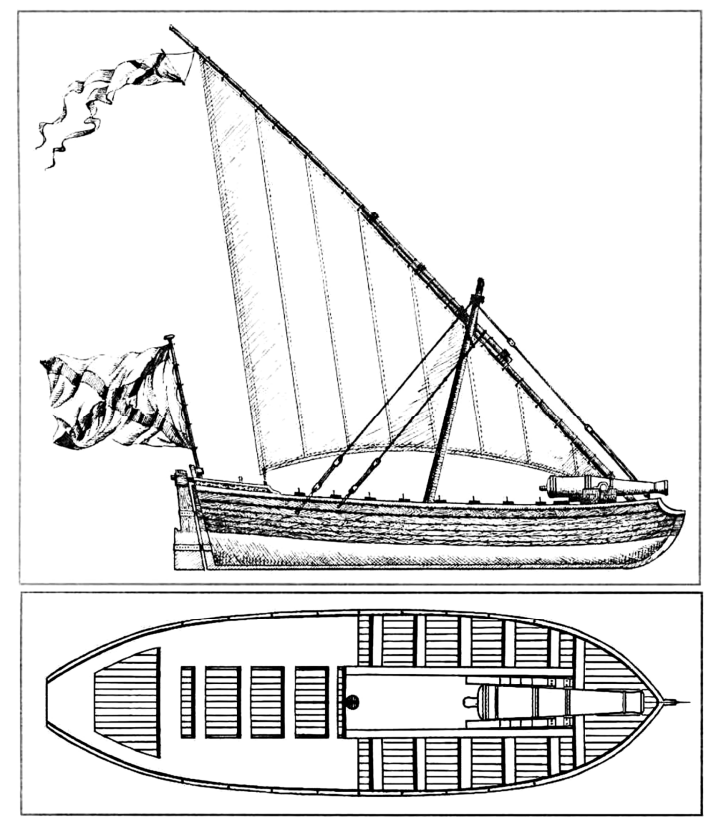

Рис. 1. Канонерський човен (1788 р.)

\footnotetext{
${ }^{7}$ Общий морской список. Ч. ІІІ. Санкт-Петербург, 1890. С. 430.

${ }^{8}$ Аргатюк С.С., Левчук В.В., Сапожников И.В. Указ. соч. С. 151-152.
} 
Важлива інформація про стан Дністровської флотилії міститься у доповіді адмірала M.C. Мордвинова з Аджидеру імператриці Катерині II від 25 липня 1793 р. Зокрема адмірал звітував про те, що залишена ескадра потребувала ремонту, оснастки та поповненням артилерією. Після особистого інспектування адмірал залишився задоволений станом флотилії в Аджидері, зауваживши, що іï він «знайшов у справності, і вона не тільки в силах забезпечити лиман Дністровський від супротивника, але і в змозі завдати йому значної поразки». До звіту додавався опис флотилії. Згідно «Відомості суднам Дністровській ескадрі» у ній було: 5 номерних лансонів (№№ 7, 18, 19 - на кожному судні по одній 18фунтовій і 3-фунтових чавунних гармат; №№ 20-21 - по одній 18-фунтовій гарматі), 4 скампавеї (№№ 1-4, на кожній по два 3-фунтових єдинороги), 14 військових човнів (озброєних однопудовою мортирою, 8-фунтовими єдинорогами і турецькими мідними гарматами калібром $16 \frac{1}{2}, 14,13 \frac{1}{2}, 12,9,7,6,3^{1} \frac{1}{2}$ фунтів). Більше того, до ескадри було прираховано бомбардирське судно № 1, яке знаходилося у Херсоні, де на нього мали встановити 5-пудову мортиру. Всього 24 судна. Скоріше за все, основу Дністровської (Овідіопольської) ескадри складали лансони, захоплені у турків протягом 1788-1790 рр. Відомо, що їх виправив та озброїв ще у 1790 році капітан-лейтенант І.Г. Бардака. Тоді ж вони отримали імена святих.

Кількість екіпажів вказана в іншій відомості, вірніше у рапорті Й.М. де Рібаса на ім'я П.О. Зубова. Згідно документу від 04.11.1793 р., на суднах в Аджидері знаходилося 336, на березі 62, а всього 398 військових і моряків. При цьому загальна кількість службовців Гребного флоту складала 4385 осіб, до числа яких входили: флотських - 2016, батальйонних - 1203, морської артилерії - 166, польової артилерії - 438, гренадерських полків і єгерських батальйонів - 531, адміралтейських - 31. Таким чином на той момент Дністровська флотилія складала третину Чорноморського Гребного флоту, що базувався біля Гаджибея (Аджибея), і 9,1\% від його загального складу. Правда тут не враховано полки, які були приписані до Гребного флоту, в разі бойових дій і посадки їх на судна.

31794 року на Гребному флоті знову розпочали використовувати козаків Чорноморського флоту, зібраних з різних місць у Гаджибеї, згідно наказу О.В. Суворова. Частину їх призначили у Гаджибей на 12 човнів і в Аджидер на 2 човни. У зв'язку з цим віцеадмірал Й.М. де Рібас 14 серпня того ж року доповів віце-адміралу М.С. Мордвинову, що «тих козаків кілька партій сюди [в Гаджибей] і прибуло, човни для них призначені приписані до Дністровської ескадри».

Взимку 1794-1795 рр. в Овідіополі біля причалів і на березі знаходилися усі судна Дністровської ескадри. Міра ця була вимушеною, оскільки зазвичай вони зимували біля Хаджибея, потім у Миколаєві, Очакові та в інших місцях Дніпро-Бузького лиману, так як Дністровський лиман замерзав повністю. Причиною цьому був наказ коменданта османської фортеці Аккерман закрити гирло для виходу російських військових суден з Дністровського лиману. Тоді Чорноморське адміралтейство, для запобігання непорозуміння 3 турками, заборонило виводити ескадру з порту та гавані Овідіополя у море до початку весни ${ }^{9}$.

Після відсторонення віце-адмірала Й.М. де Рібаса від командування Гребним фло-

\footnotetext{
${ }^{9}$ Аргатюк С.С., Левчук В.В., Сапожников И.В. Указ. соч. С. 152-154.
} 
том 18 грудня 1796 р., його місце зайняв контр-адмірал П.В. Пустошкін, який до кінця 1797 р. одночасно був градоначальником Одеси та комендантом порту. 7 березня 1797 р., після проведеної інспекції Чорноморського флоту, контр-адмірал П.К. Карцов звітував імператорові Павлу I: «військові судна, розташовані біля Одеси і на Дністровському лимані біля Овідіополя, мною оглянуті й артилерією оснащені, як такелажем і парусами». На той час в Овідіопольській ескадрі був один бомбардирський катер і сім лансонів 3 командою у 228 моряків (Додаток).

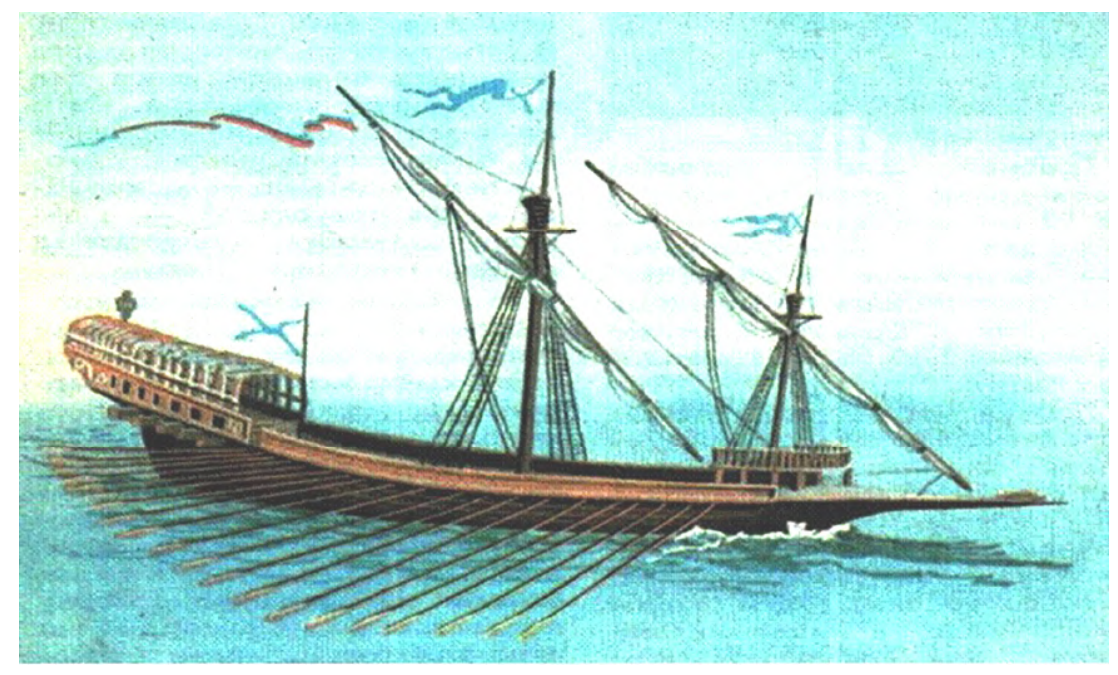

Рис. 2. Скампавея (напівгалера) XVIII ст.

10 червня 1797 р. імператор Павло I своїм указом приписав П.В. Пустошкіну утримувати на Дністрі невелику ескадру, яка складалася з катера, 8 лансонів і 4 скампавей (Рис. 2). Виконуючи наказ імператора П.В. Пустошкін здійснив вояж-інспекцію з 36 суднами Гребного флоту від Одеси до Очакова, а потім до Дністра, куди прибув 10 липня, а звідти знову рушив до Очакова. Невдовзі був представлений звіт. у «Журналі кампаній контр-адмірала Пустошкіна в 1797 р.» подані відомості про кількість суден та їх команд, які мали плавання від Дністра до гирла Дніпра (Додаток) ${ }^{10}$.

Невдовзі до зазначеного складу додали 15 канонерських човнів, які доправили до Дністра у супроводі бригантини «Мокей» під орудою нового командира Овідіопольської ескадри бригадира I.Т. Овцина. 10 липня П.В. Пустошкін доповів з брига «Іларіон», що 6 червня човни прибули до Овідіополя. У зв'язку з тим, що бомбардирський катер і 7 лансонів були не придатні для використання через свою «ветхость», той же бригадир П.В. Овцин доправив їх до Очакова, а потім - у Миколаїв. 31798 р. Дністровською флоти-

\footnotetext{
${ }^{10}$ Журнал кампании контр-адмирала Пустошкина в 1797 году // Собрание морских журналов или ежедневных записок, содержащих в себе плавания флотов, эскадр и судов Российских, начиная с 1797 года, то есть со времени вступления на престол Его императорского величества государя императора Павла Петровича, издаваемого по Высочайшему повелению, попечением и трудами вице-адмирала, Государственной адмиралтейской коллегии члена, историографа по флоту и начальствующего в учрежденном при сей коллегии комитете Александра Шишкова. Ч. 2. Санкт-Петербург, 1800. С. 38-46.
} 
лією командував капітан-лейтенант П.І. Шостак ${ }^{11}$

У ці ж роки (з 1796 р.) Х.Б. де Граве знаходився у Миколаєві при береговій флотській команді, а наступного року їі очолив. 1798 року він зайняв посаду командира Миколаївського гарнізону, а також був презусом (головою) рахункової комісії військового суду. У 1799 р. став членом військового суду у Миколаєві, після чого його відрядили для опису порогів рр. Південний Буг і Синюха, у тому ж році повернувся до Миколаєва. 12.10.1798 p. отримав звання капітана 2-го, а 14.04.1801 р. - капітана 1-го рангів. У 1802-1803 рр. командував кораблем «Марія Магдалена» на Чорному морі. 17.10.1803 р. вийшов у відставку $^{12}$. Останні роки життя Х.Б. де Граве пов'язані саме з Миколаєвом, де він збудував будинок на розі вулиць Фалеєвської та Адміральської.

Неподалік від Одеси поміж Куяльницьким і Хаджибейським лиманами Х.Б. де Граве мав земельний наділ (2950 дес. на ділянці № 41) ${ }^{13}$. У подальшому вказана земельна дача перейшла до генерал-лейтенанта Ф. Кобле, а потім була продана графу Августу (Юзефу) Іллінському, на якій у 1810 р. виникло с. Августовка (Іллінка) ${ }^{14}$. Під час розбудови Гаджибея «капит.-лейт. Бернард де Граве» у 1794 р. виділили подвійну ділянку під забудову в центрі міста на Грецькому форштадті (VII квартал, № 61 і № 64) ${ }^{15}$.

На жаль, ми не маємо портретів цієї видатної особистості, але зберігся опис одного 3 них: «Граве, Христофор-Бернар. Капитан флота, писатель. Сидит в расстёгнутом сюртуке, в очках, с Владимиром на шее и Георгием 4 ст., со скрипкою в руках, поджавши ноги; ниже колена». Літографію виконав художник Ф.И. Гросс (Gross F.) ${ }^{16}$.

В одному з довідників письменників Російської імперії Х.Б. де Граве зазначений як співробітник журналу М.І. Невзорова «Друг юношества» (1809-1810 pp.) ${ }^{17}$. А у книзі I.Ф. Масанова є інформація про те, що Х.Б. де Граве друкувався у 1808 р. в названому журналі під псевдонімом «Х.Б.Г. - Христоф. Бернард, Граве» ${ }^{18}$. Крім того, він видав у 1807 р. в Миколаєві свою працю: «Теоретико-практическое наставление о гражданской архитектуре. В пользу домостроителей собрано из лучших писателей с приличным чертежем» ${ }^{19}$. Це рідкісне видання розділено на три частини: у 1-й йдеться про міцність будівель; у 2-й -

\footnotetext{
${ }^{11}$ Аргатюк С.С., Левчук В.В., Сапожников И.В. Указ. соч. С. 156-158.

${ }^{12}$ Общий морской список. Ч. ІІІ. Санкт-Петербург, 1890. С. 430.

${ }^{13}$ «План дач местечка Севериновка, сел Эметка, Марьяновка, Куницовка, С.О. Потоцкого, Найденовского, Миноса, Кованьки, Х. Бернар де Граве и др.». Экспликация плана по извлечению межевой конторы. Сочинена сентября месяца 1820 г. // Державний архів Херсонської області (ДАХО). Ф. 302. Оп. 1. Спр. 1041.

${ }^{14}$ Ведомость Тираспольского уезда о количестве земель казенных и помещичьих дач, значущиеся по уездному плану с показанием составленных к последующей 1811 года ревизии мужеского пола // ДАХО. Ф. 14. Оп. 17. Спр. 1. Арк. 50.

${ }^{15}$ Застроение города Гаджибея, теперь Одессы, в 1794 году // Записки Одесского Общества истории и древностей. Одесса, 1853. Т. 3. С. 593.

${ }^{16}$ Адарюков В.Я., Обольянинов Н.А. Словарь русских литографированных портретов. Т. 1: А-Д. Москва, 1916. C. 255.

${ }^{17}$ Венгеров С.А. Источники словаря русских писателей. Т. 1: Аарон-Гоголь. Санкт-Петербург, 1900. С. 78.

${ }^{18}$ Масанов И.Ф. Словарь псевдонимов русских великих ученых. Т. 3: Псевдонимы русского алфавита: Р-Я. Москва, 1958. С. 210.

${ }^{19}$ Геннади Г. Справочный словарь о русских писателях и ученых, умерших в XVIII и XIX столетиях и список русских книг с 1725 по 1825 г. Т. 1: А-Е. Берлин, 1876. С. 249.
} 
про зручність, а у 3-й - про естетичний смак зовнішнього і внутрішнього оздоблення ${ }^{20}$.

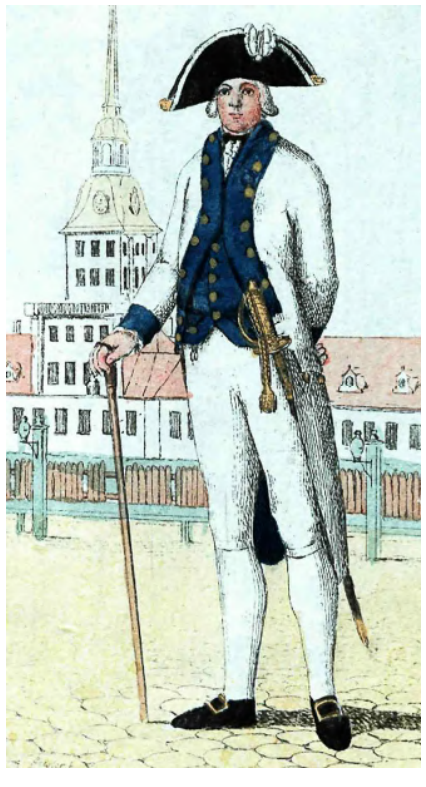

Рис. 3. Флотський корабельний офіцер 1793 p.

(мал. Х. Гейслера 1793 р.)

Більш детальна інформація про Христофора Бернарде-Граве є у Записках Одеського товариства історії і старожитностей: «Бернар де Граф (Бернар де Граве) Христофор, капітан 1-го рангу; прусського походження; $з$ дворян; грецького віросповідання; 51 рік (у 1809 р.); вчитель математики, геодезії, фізики, фортифікації і артилерії в [Одеському] Благородному інституті 31 листопада 1809 р.; має 3 синів і 5 доньок; у Санкт-Петербурзькому намісництві у Гдовському повіту мав 14 душ селян. 31764 по 1772 р. знаходився в морському шляхетському корпусі; служив на флоті: по 1785 р. на Балтійському, а 3 того часу - Чорноморському. 3 24 травня 1803 р. по 17 жовтня 1803 р. знаходився на Гребному Балтійському флоті. 17 жовтня 1803 р. через хворобу відсторонений від служби капітаном 1-го рангу і за 30-річну службу - 3 половинним жалуванням. 17 березня 1812 р. помер» ${ }^{21}$.

Дружиною Х.Б. де Граве була Катерина Іванівна. 3 1829 по 1838 рр. вона зазначалася в «Месяцесловах» по Одеському народному дівочому училищу, як «капітанша 1-го рангу», наглядачка Катерина Іванівна Бернард де Граве ${ }^{22}$; i лише за 1833 р. - вказана як «вдова капітана 1-го рангу» 23. На 1840 р., по відомству міського дівочого училища від Одеського інституту благородних дівиць, крім наглядачки К.І. Бернард де Граве названі її помічниці, дівиці Анна та Єлизавета Христофорівни Бернард де Граве $\mathrm{e}^{24}$, на 1849 р. вони вже були наглядачками ${ }^{25}$. Зрозуміло, що це доньки капітана, які згодом мешкали у Керчі та були поховані на старому цвинтарі міста як «Анна и Елизавета, девицыљ (без дат) ${ }^{26}$. Єлизавета Бернард де Граве була свідком при хрещені 28.11.1841 р. у Петропавлівській церкві с. Петроверівка Володимира сина колезького секретаря Павла Степановича Андрієвського iз с. Єлизаветівки Одеського повіту. Ще одним свідком був колезький секретар Єгор Христофорович Бернард де Граве ${ }^{27}$ - син нашого героя.

Є.Х. Бернард де Граве (бл. 1810-1867), статистик, секретар Кримського економіко-

\footnotetext{
${ }^{20}$ Буриев А.Е. Библиографическое описание редких и замечательных книг. Т. VII. Санкт-Петербург, 1901. C. 247.

${ }^{21}$ Алфавитный список лиц, служивших в Одесской коммерческой гимназии и Благородном институте, или имеющих какие-либо отношения к этим заведениям // Записки Одесского общества истории и древностей. 1904. T. XXV. C. 341.

${ }^{22}$ Месяцеслов с росписью чинов особ, или общий штат Рос. империи, на лето от Р.Х. 1829. Ч. 1. СанктПетербург. 1828. С. 587; Месяцеслов и общий штат Рос. империи на 1838. Ч. 2. Санкт-Петербург, 1837. С. 197.

${ }^{23}$ Месяцеслов и общий штат Российской империи на 1833. Ч. 1. Санкт-Петербург, 1832. С. 560.

${ }^{24}$ Новороссийский календарь на 1840 год. Одесса. 1839. С. 144.

${ }^{25}$ Новороссийский календарь на 1849 год. Одесса. 1848. С. 314-315.

${ }^{26}$ Река времен. Кн. 4: Русский провинциальный некрополь. Москва, 1996. С. 33.

${ }^{27}$ Російський державний історичний архів (РДІА). Ф. 1343. Оп. 3. Спр. 1652-б. Арк. 19.
} 
статистичного комітету. Друкував свої статті у «Пам'ятних книжках Керч-Єнікальского градоначальства» $(1860,1863)$. Освіту отримав у Рішельєвському ліцеї. Після закінчення курсу, учитель Одеського, а з 1834 - Кишинівського повітового училищ (указ від 15.10 .1833 р.), з 1835 - знову учитель Одеських повітових училищ ${ }^{28} .331$ березня 1838 р. по 10 грудня 1839 р. секретар Одеського цензурного комітету ${ }^{29}$. На 1847 рік мав чин колезького асесора, числився комісіонером Керченського карантину з 15 листопада 1844 р. ${ }^{30}$ у 1850-х рр. служив по відомству Дирекції громадських бібліотек Керч-Єнікольського градоначальства. На 1861 р. у чині колезького радника був членом Керченського карантинного округу ${ }^{31}$. Є.Х. Бернард де Граве (помер 22.12.1867 р.) і його дружина Анна Дмитрівна (померла 24.02.1866 р., на 34 році) також поховані на старому цвинтарі у Керчі ${ }^{32}$.

Маємо деякі відомості і про другого сина - Івана Христофоровича, який народився у 1805 р. Він був командиром транспорту «Мамай». Згаданий у рапорті командира Севастопольського порту віце-адмірала А.П. Авінова про захоплення турецьких суден з контрабандистами 20.05.1841 p. 33 Згодом служив капітаном на шхуні «Вестник» (1843-1844 pp.) ; $^{34}$ командиром 16-гарматного брига «Персей» (1845-1849 рр.). У списку на 1848 р. значився капітан-лейтенантом Чорноморського флоту ${ }^{35}$, а у 1850-1852 рр. командував 44-гарматним фрегатом «Кагул» ${ }^{36}$ 10-11 березня 1854 р. у чині капітана 2-го рангу I.X. Бернард де Граве очолив загін козацької дунайської флотилії з 7 бойових суден (1 пароплав і 6 канонерських човнів), який діяв проти турецьких укріплень під час переправи російських військ через Дунай біля Мачинського рукава ${ }^{37}$. Отримав звання капітана 1-го рангу і знаходився при головнокомандуючому Південної армії М.О. Горчакові для особливих доручень, а у 1860-х рр. займав посаду начальника морських команд у м. Керчі ${ }^{38}$. Дослужився до чину генералмайора. Помер 06.02.1869 р. і був похований у Керчі. Про інших дітей відомостей мало.

Повертаючись до Дністровської ескадри, зазначимо, що для розуміння того, де власне розміщувалась база Дністровської ескадри, важливими є три плани кінця XVIII ст. ${ }^{39}$ Судячи

\footnotetext{
${ }^{28}$ Бобков В.В. Статистики Таврической губернии (XIX - начало XX) века: библиографический указатель. Симферополь, 2004. С. 111.

${ }^{29}$ РДІА. Ф. 772. Оп. 1. Спр. 1078, 1290.

${ }^{30}$ Список чинам VIII класса. Санкт-Петербург, 1847. С. 1353.

${ }^{31}$ Новороссийский календарь на 1861 год. Одесса, 1860. С. 343.

${ }^{32}$ Река времен... С. 33.

${ }^{33}$ М.П. Лазарев. Документы / А.А. Самаров (ред). Т. 2. Москва, 1955. С. 329, 655.

${ }^{34}$ Соллогуб В.А. Повести, воспоминания. Ленинград, 1988. С. 692.

${ }^{35}$ Новороссийский календарь на 1849 год. Одесса, 1848. С. 275.

${ }_{36}$ Чернышев А.А. Российский парусный флот: Справочник. Т. 1. Москва, 1996. С. 244.

${ }^{37}$ Олійників О. Українці в Кримській війні. Одеса, 2004. С. 98.

${ }^{38}$ Новороссийский календарь на 1860 год. Одесса, 1859. С. 356.

39 «План Гаджидерских укреплений с показанием проведенных работ ноября с 1-го 1793-го года по первое ноября 1794 года. Покрытая красною красною значит, что зделано в нынешнем 1794-м году при укреплениях. Желтою красною, что следует окончить. А красною красною покрытая Адмиралтейское строение и водопровод назначаются вновь к построению»; «План Овидиопольской крепости и предместию оной с показанием около крепости местоположения, и нивелировки оной на семь сот пятьдесят сажен. Сочинен при Овидиопольской инженерной команде 1798 году августа 5 дня»; «Планы, прорезы и фасады казарм для морских служителей. Сочинен при Овидиопольской инженерной команде июля 25 дня 1798 году». Зберігаються в Російському державному військово-історичному архіві (РДВІА. Ф. 349. Оп. 27. Спр. 23-24, 31). Копії люб'язно надані архітектором А. Ізотовим.
} 
3 першого з них, складеного Ф.П. де Воланом у листопаді 1794 р., на вказаний час було збудовано лише дві казарми для морських екіпажів (позначені літерою «F»; див. нижче). Планувалося збудувати: правління Дністровської ескадри (№1), будинок для морського начальника (№ 2), два офіцерські будинки (№3), казарми для морських службовців (№ 4), «полагаемую пристань» і навіть водогін з труб (№ 6), що мав подавати питну воду з джерел, які досі існують і звуться «Кринички». Усі будівлі морського відомства мали знаходитись всередині земляного укріплення - власне «Адміралтейства» (його контури позначені пунктиром). У самій фортеці тривало зведення нижнього укріплення на береговій терасі, яке призначалося «для оборони рейду і прикриття будівель Дністровської ескадри» (літера «В») ${ }^{40}$.

Однак, на другому плані, підписаному через чотири роки Є.Х. Ферстером, показано, що Адміралтейство в Овідіополі не було зведено. Під номерами в поясненнях і на плані наявні: «Ветхие адмиралтейские строения» (№ 13), «Каменные казармы, для морских служителей, с 3-я землянками» (№14), «Исправная адмиралтейская пристань для гребных судов» (№ 15), а на рейді - 14 суден «Днестровской эскадры» (№ 28). Неподалік від причалу ескадри (на схід від нього) існував інший причал, який належав карантину (№ 17), а, можливо, і соляному магазину (№ 17; Рис. 4).

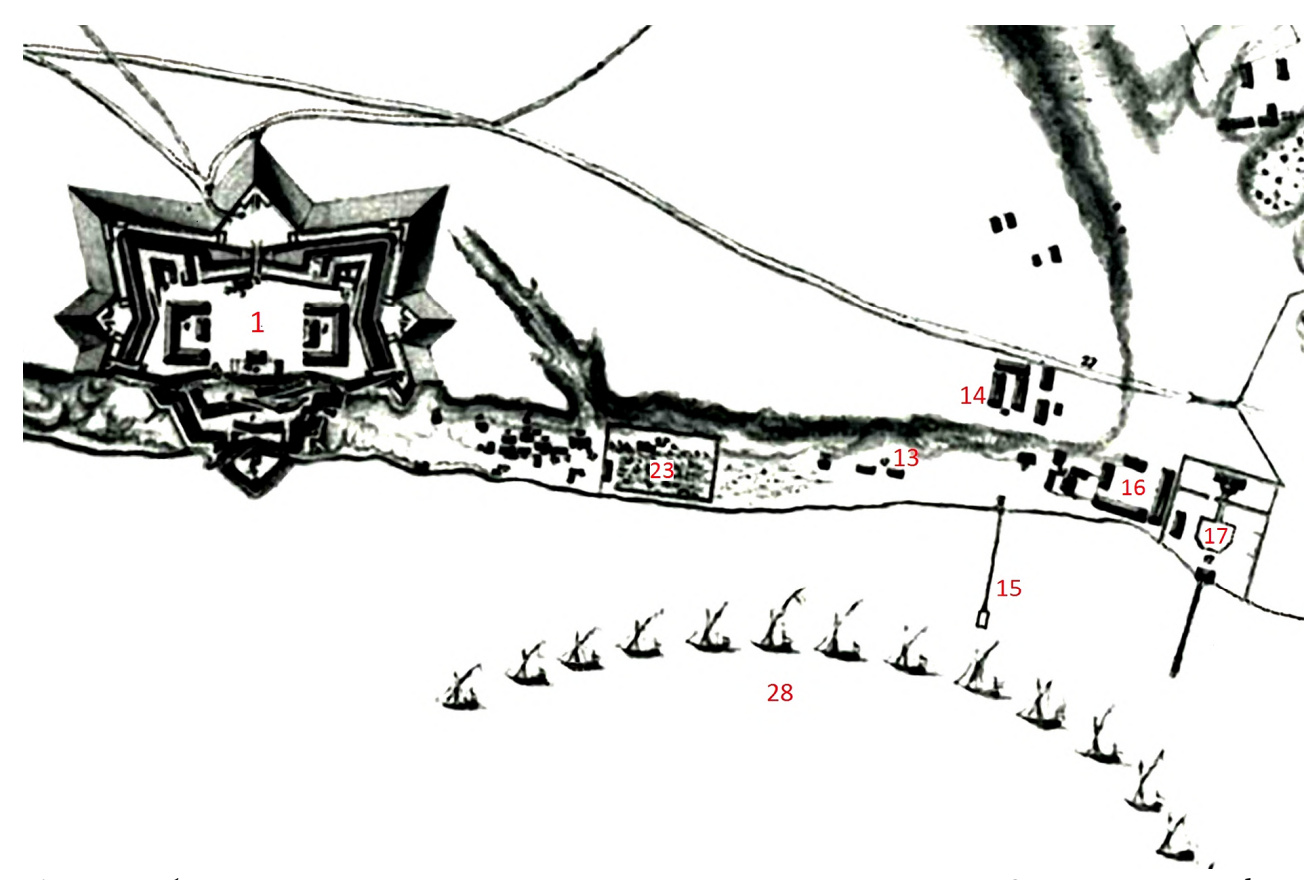

Рис. 4. Місце базування Дністровської ескадри на «Генеральному плані Овідіопольської фортеці» 1798 р. (1 - Овідіопольська фортеця; 13 - Старі адміралтейські будівлі; 14 - Кам'яні будівлі для морських службовців з 3 землянками; 15 - Виправлена адміралтейська пристань для гребних суден; 16 - Кам'яний соляний магазин; 17 - Карантин з будівлями і пристанню; 23 - Старий полковницький будинок з фехверка з садом (інженера Є. Ферстера); 28 - Дністровська ескадра на рейді.

\footnotetext{
${ }^{40}$ Цей план спростовує датування плану Ф. Кауффера Овідіопольської фортеці 1793 р.: Красножон А.В. Фортеці і міста Північно-Західного Причорномор'я. Одеса, 2018. С. 254. Див.: Сапожников И. Рец. на: А. Красножон. Фортеці та міста Північно-Західного Причорномор'я (XV-XVIII ст.). Одеса, 2018. 312 с. // Tyragetia. 2019. Vol. XIII. № 2. C. 353.
} 


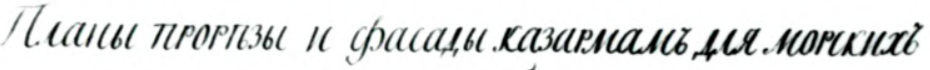

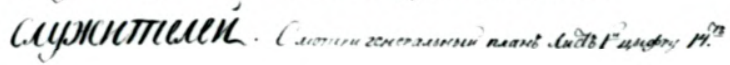

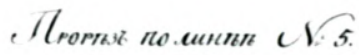

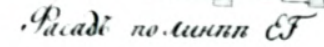

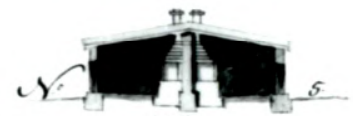

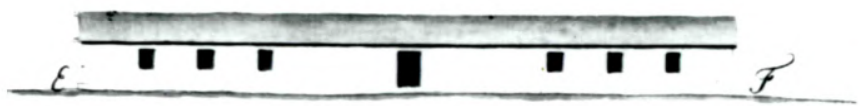

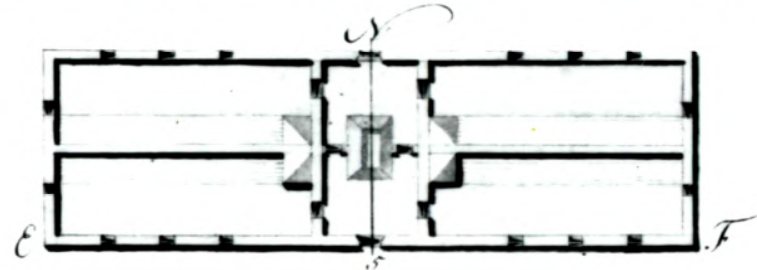

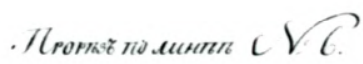

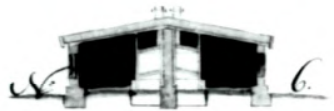

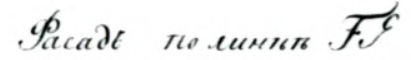
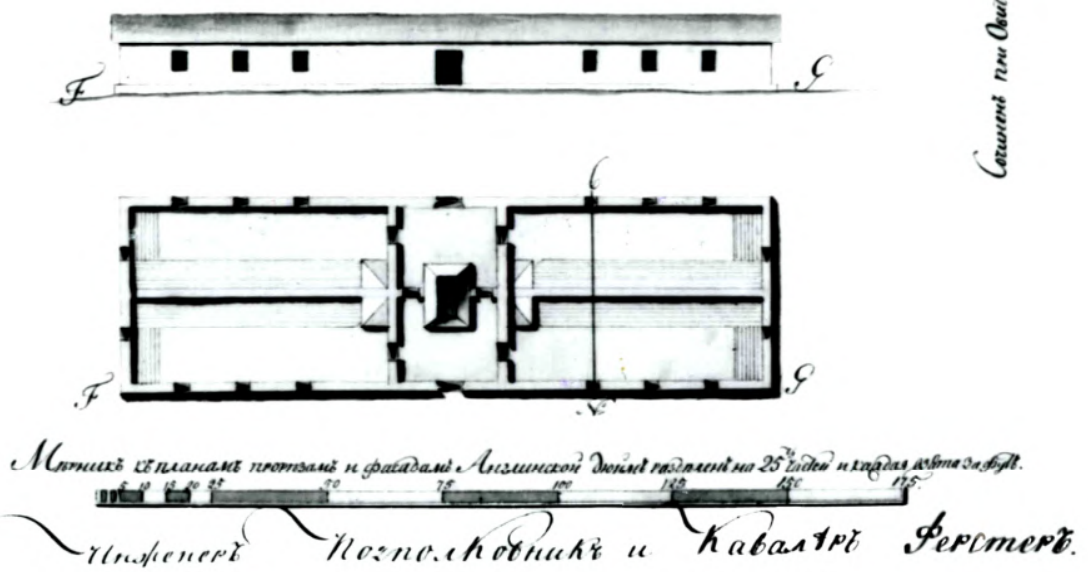

Рис. 5. Морські казарми в Овідіополі (1798 р.)

Збереглися й креслення казарм для морських службовців. Як видно із плану (Рис. 3), це була витягнута одноповерхова чотирьохкімнатна будівля. Вхід розміщувався посередині, права і ліва сторони від входу займали самі казарми. Вони у свою чергу були поділені на дві частини з окремими входами зсередини та мали невеликі вікна по фасаду.

Останній епізод історії Дністровської ескадри пов'язаний з подіями 1806-1807 рр., коли головною діючою особою став інший Пустошкін - Семен Афанасійович (1759- 
1846 рр.). 30 грудня 1806 р. він виступив з Миколаєва з усім Гребним флотом, який складався 380 канонерських човнів і 6 фрегатів до Одеси для захисту їі від турків, куди прибув 15 листопада. Через 5 діб контр-адмірал рушив до Дністровського лиману, маючи під своєю командою 44 канонерські човни і 3 мілких парусних судна. Флотилія допомогла військам у захопленні фортеці Аккерман, а пізніше перебазувалася у Кілію, де отримала назву Дунайської ${ }^{41}$.

Отже, хоча Дністровська ескадра проіснувала недовго, і не брала участі у військових діях, вона зіграла свою роль у захисті кордону з Османською імперією, що проходив по р. Дністер і Дністровському лиману, напередодні російсько-турецької війни 1806$1812 \mathrm{pp}$.

Відмітимо також, що до Дністровської ескадри, крім зазначених вище, також мали відношення командири суден Чорноморської Гребної флотилії, у тому числі: мічмани Д.Д. Протопопов, ̆.Й. Ситенський, Я.П. Савицький; лейтенанти А.П. Орн, А.Ф. фон Штейн, Д.С. Поскочин, Є.Д. Бороц (Бароцщі); капітан-лейтенанти I.І. Фоллет, Ф.Д. Свищов, І.С. Зелений, І.А. Данненберг, Ф.П. Метакса, М.М. Трегубов; капітан 1-го рангу Б.А. Асланбегов; капітани 2-го рангу М.І. Єфим'єв, Г.В. Левін, П.Д. Савицький; майбутні контр-адмірали Д.Є. Бальзам і О.Ф. Сільва; майбутній генерал-лейтенант Г.П. Лобисевич (1-й). Але найвідомішим серед них був капітан-командор Й.Й. Білінгс, який, командуючи бомбардирським судном «Різдво Богородиці», здійснив опис узбережжя Чорного моря біля о. Тендри, Очакова, Одеси та гирла Дністра ${ }^{42}$. Усі ці моряки мешкали в Аджидері (Овідіополі) й у Миколаєві, але їх біографії чекають своїх дослідників.

\section{Sergey Argatiuk, Igor Sapozhnikov}

\section{The Dnister squadron of the Black sea Rowing Fleet and its Commander Christopher Bernard de Grave}

Abstract: The article is devoted to the history of the Dniester squadron, founded after the Russo-Turkish war of 1787-1791, which was a structural unit of the Black Sea Rowing Fleet, based in Nikolaev and Odessa. It also describes the biography of the first commander of the Dnister Flotilla, H.B. de Grave, much of whose life and activities were also related to both cities. The article first presents plans indicating the naval structures in Adzhider (Ovidiopol) in 1794 and 1798, which were carried out by F.P. de Wolan and E.H. Ferster. Attached is a detailed report by Rear Admiral P.V. Pustoshkin about the 1797 campaign that sheds light on the structure and activities of the entire Crested Fleet during the reign of Emperor Paul I.

Keywords: Agider, Ovidiopol, Dniester flotilla, Captain Christopher Bernard de Grave, Nikolaev

\footnotetext{
${ }^{41}$ Аргатюк С.С., Левчук В.В., Сапожников И.В. Вказ. праця. С. 165.

${ }^{42}$ Ibid. C. 159-162.
} 


\section{Журнал кампании контр-адмирала Пустошкина в 1797 году}

По высочайшие его императорские величества указу, состоявшемуся марта в 31 день, повелено было контр-адмиралу Пустошкину из порученного ему Черноморского Гребного флота вооружить 3 бригантины, 6 лансонов и 27 канонерских лодок и с сей эскадрой идти в море для обучения офицеров и служителей морским эволюциям и прочим действиям, имея плавание около берегов от устья реки Днестра до лиманов Днепровских. Вследствие сего повеления приуготовлены были в Николаевском и Одесском портах нижеследующие суда:

\begin{tabular}{|c|c|c|c|}
\hline Имена судов & Имена флагманов и капитанов & $\begin{array}{l}\text { Число } \\
\text { пушек }\end{array}$ & $\begin{array}{r}\text { Число } \\
\text { служи- } \\
\text { телей } \\
\end{array}$ \\
\hline Бригантины: & & & \\
\hline Ларион & $\begin{array}{l}\text { контр-адмирал } \quad \text { Пустошкин, } \\
\text { лейтенант Сальков }\end{array}$ & 10 & 127 \\
\hline Мокей & $\begin{array}{l}\text { бригадир Овцын, капитан-лейтенант Герпель } \\
\text { капитан 2-го ранга Пустошкин, лейтенант }\end{array}$ & 10 & 102 \\
\hline Павел & Ендоуров & 10 & 91 \\
\hline Лансоны: & & & \\
\hline Феодор & лейтенант Филипов & 6 & 42 \\
\hline Мирон & лейтенант Пилипенко & 6 & 37 \\
\hline Антип & лейтенант Эрли & 5 & 42 \\
\hline Родион & лейтенант Туровский & 5 & 37 \\
\hline Дионисий & лейтенант Эленгал & 5 & 36 \\
\hline $\begin{array}{l}\text { Иерофей } \\
\text { Лодок }\end{array}$ & лейтенант Каламатьяно & 5 & 38 \\
\hline Бомбардирских 3 & Из оных бомбардирские имели на себе по & & \\
\hline Канонерских 24 & $\begin{array}{l}\text { одной мартире и по два единорога, а кано- } \\
\text { нерские по одной пушке. Над каждой лодкой } \\
\text { начальствовал офицер. } \\
\text { Сверх сего все оные разделены были на три } \\
\text { равные части или дивизии, из коих первой } \\
\text { командовал лейтенант Дегаллет, второй лей- } \\
\text { тенант Бароцци, а третьей лейтенант На- } \\
\text { вроцкий }\end{array}$ & 33 & 834 \\
\hline Итого всех судов & На оных: & 95 & 1356 \\
\hline
\end{tabular}

/39/ По вооружении сих судов, все оные в мае месяце собрались от Одесского и Николаевского портов на Глубокую пристань, лежащую при устье Днепра. 
Июня 1 числа, при восточном умеренном ветре, вся эскадра, снявшись с якоря и построясь во второй походный строй, имела плавание лиманом к морю; потом, составя три колонны, и выйдя из лимана, при острове Березань стала на якорь.

2 числа во втором походном строе пришла на Одесский рейд, на котором расположась линией на якоре простояла по нижеследующее число, обучая по временам служителей пушечной и ружейной экзерциции примерно. /40/

5 числа, при бывшем от NO маловетрии, учинен сигнал: сняться с якоря и построиться в три колонны; но по воспоследовавшему противному от юга ветру, поднят вторичный сигнал, возвещавший, что прежний ордер отменяется. Между тем эскадра лавировала по способности каждого судна, пока крепкий юго-западный ветер не понудил оную возвратиться в Одесскую бухту и стать на якорь.

6 числа показалась в море к юго-востоку российская корабельная эскадра, состоявшая в 9 военных судах, под начальством вице-адмирала Ушакова, чего ради контрадмирал Пустошкин, со всеми порученными ему гребными судами, вышел на встречу к оной, и по учинении между флагманами обеих эскадр взаимного салюта, Гребная из оных возвратилась назад в Одесскую бухту, а Корабельная, по причине усилившегося ветра, приблизясь к берегу, остановилась на якорь.

8 числа Корабельная эскадра ушла паки в море, а на другой день контр-адмирал Пустошкин с Гребной флотилии своей, при тихом северо-западном ветре, снявшись с якоря, отправился к устью реки Днестра. До полудни шли они греблею, устроясь в три колонны, а после полудня, при наставшем от юго-запада ветре, лавировали, и наконец в 14 /41/ верстах от мыса Днестровских Гирл, стали на якорь.

10 числа поутру, при тихом северном ветре, вступив под паруса, направляли путь свой к Днестровскому устью, куда вскоре пришед, расположились на якорях между Очаковскими и Цареградскими гирлами. В сем месте производили пушечную экзерцицию с пальбою. После чего, при тихом юго-западном ветре, снявшись паки с якоря, и построясь в три колонны, во весь остаток дня и во всю последующую ночь продолжали плавание к Днепровскому лиману, и на другой день поутру прибыли к оконечности Кинбурнской косы. Тогда бригантины и лансоны остановились на фарватере, а лодки приближились к Очаковскому берегу. Во весь сей день и наступившую потом ночь ветер был ZZW крепкий

12 числа, по утишении ветра вся эскадра пришла на Очаковский рейд, где на другой день производила ружейную экзерцицию с пальбой.

15 числа авангардия, состоящая из 12 судов под начальством бригадира Овцына, по сигналу главнокомандующего, снявшись с якоря и отошед на 7 верст к востоку, делала разные эволюции, и потом возвратились паки к эскадре; а на другой /42/ день тоже самое чинила аръергардия, состоящая из такого же числа судов под начальством капитана 2-го ранга Пустошкина. На судах же остававшихся на рейде, производима была пушечная и ружейная экзерциция примерно, також служители обучаемы были действию снастей и парусов.

17 числа, при южном ветре, вся эскадра в ордера двух колонн отправилась к Одесса, куда прибыв по полудни в 11 часов, стала на якорь. В продолжение стояния на Одесском рейде, по нижеследующее число, принимаема была на эскадру из тамошних магазинов морская провизия, служители обучались отдаванию и креплению парусов, также неодно- 
кратно производилась пушечная и ружейная экзерциция примерно и с пальбою.

23 числа, по данному от главнокомандующего сигналу, вся эскадра снялась с якоря от Одессы к Очакову. Переход сей при умеренном северном ветре продолжался 10 часов.

24 числа получено высочайшее повеление о учреждении на реке Днестре Гребной эскадры, которая бы состояла из 1 катера, 8 лансонов и 4 скампавей, или же хотя и из других судов, какие для сего нужнее и способнее быть могут. /43/

25 числа контр-адмирал Пустошкин отправился со всей эскадрой от Очакова паки к Одессе, куда, по причине задержавших его противных ветров, не прежде прибыл, как через двое суток, и по прибытии своем, во исполнение полученного им высочайшего повеления, учинил следующее: Поскольку эскадра на Днестре под именем Овидиопольской и прежде того существовала, состоя из 1 катера и 7 лансонов, большей частью в ветхость пришедших; того ради положено было эскадру сию возвратить в Николаевский порт, а на Днестре, по силе указа, учредить новую, для которой за способнейшие суда сочтены канонерския лодки, и потому назначено из числа бывших в эскадре контр-адмирала Пустошкина 27 отправить туда 15 лодок, которым и составлять там особое отделение.

Июля 2 числа, по снабжению вышепомянутого числа канонерских лодок всем нужным, посланы оные были в назначенное им место, под начальством бригадира Овцына, провожавшего их на бригантине Мокее. Между тем остальная часть эскадры контрадмирала Пустошкииа, стоя на Одесском рейде, обучалась по временам пушечной и ружейной экзерциции, также действию снастей и парусов.

9 числа бригадир Овцын, проводя вверенные ему лодки до устья Днестровского лимана, возвратился /44/ обратно в Одессу, и привел с собой бывшую на Днестре Овидиопольскую эскадру, состоявшую в следующих судах:

\begin{tabular}{|l|l|c|c|}
\hline \multicolumn{1}{c|}{ Имена судов } & Имена флагманов и капитанов & $\begin{array}{c}\text { Число } \\
\text { пушек }\end{array}$ & $\begin{array}{c}\text { Число слу- } \\
\text { жителей }\end{array}$ \\
\hline \begin{tabular}{l|c|c} 
Бомбардирский катер Гром \\
Лансоны:
\end{tabular} & лейтенант Поскочин & 1 & 35 \\
Лаврентий & лейтенант Левин & 1 & 28 \\
Марк & лейтенант Бароцци & 1 & 30 \\
Савва & лейтенант Трегубов & 1 & 29 \\
Исидор & мичман Черимов & I & 26 \\
Евдоким & мичман Савицкий & 1 & 25 \\
Андроник & мичман Троцкий & 1 & 26 \\
Ирина & порутчик Константинопул & 1 & 29 \\
\hline Итого всех судов 3 & На них: & $8^{43}$ & 228 \\
\hline
\end{tabular}

11 числа контр-адмирал Пустошкин со всеми оставшимися у него прежними и вновь пришедшими к нему судами, окончив прием из одесских магазинов на все оные морской провизии, при бывшем от юга маловетрии снялся с якоря и следовал к Днестровскому лиману. К вечеру нашел сильный от NNO шквал, оставивший по себе от той же

\footnotetext{
${ }^{43}$ Из сих орудий на катере была пятипудовая мортира, а на лансонах сверх одной 18-ти фунтовой пушки, на каждом еще по несколько фальконетов.
} 
стороны крепкий ветер; почему вся эскадра принуждена была на половине пути между Очакова и Одессы, в 15 верстах от берега, оставновиться на якорь. /45/

12 числа поутру, вступив под паруса, лавировала, а потом, за тихостью ветра, шла греблею и буксиром; к ночи же, прошед остров Березань, в 4 верстах от оного стала паки на якорь.

13 числа, при маловетрии от ZZO, бригантины верповались по фарватеру между Кинбурна и Очакова, а лансоны и лодки плыли буксиром и греблею. По приходе на Очаковский рейд, остановились на якорь, и по прошествии нескольких часов, получа умеренный от северо-запада ветер, начали снова продолжать путь свой вдоль лимана; но в тоже время увидели, что бригантина Мокей, ставшая на мель, извещала о том сигналом и требовала помощи: чего ради вся эскадра, не дошед 8 верст до устья Буга, принуждена была паки остановиться. Главнокомайдующий послал немедленно к помянутой бригантине для пособия катер свой, который по возвращении своем донес, что оная без всякого вреда с мели стянулась, и что причиной тому была поставленная на сей мели веха от сильных ветров с места своего снесенная.

14 числа, при умеренном северном ветре, вся эскадра прилавировала к устью реки Буга, и вошед в оное, за усилившимся ветром, стала на якорь. В последующие потом дни, по причине противных ветров, продолжала она плавание свое вверх по Бугу большей частью верпованием и греблею, не упуская при способных иногда переменах ветра пользоваться также и парусами. /46/

19 числа прибыла она к Николаевскому порту и расположилась на якоре в устье Ингула, где, по силе насланного об окончании кампании высочайшего повеления, и оставалась вооруженной до половины сентября месяца; после которого времени, по учинению депутатского смотра, вошла в гавань и разоружилась. 